\title{
Respon Pemberian Bokhasi Kandang Sapi Dan Berbagai Mulsa Organik terhadap Pertumbuhan dan Produksi Tanaman Pare (Momordica Charantia L.)
}

\section{Response of Giving Bokhasi Cow Cages and Various Organic Mulch toward Growth and Production of Bitter Melon}

\author{
Anna Milasarah Ritonga1), Gusmeizal 2), Erwin Pane1)* \\ 1) Program Studi Agroteknologi, Fakultas Pertanian, Universitas Medan Area, Indonesia
}

\begin{abstract}
Abstrak
Pare (Paria) merupakan sayuran buah yang mulai diminati semenjak diketahuinya kandungan zat dan varietasvarietas baru yang lebih unggul dalam hal rasa dan penampilan tanaman. Namun masih sedikit peneltian terkait budidaya pare. Rancangan yang digunakan dalam penelitian ini adalah Rancangan Petak Terbagi (RPT) faktorial yang tediri dari 2 faktor. Faktor pertama adalah pemberian mulsa organik yang ditempatkan sebagai petak utama dengan 4 taraf perlakuan yaitu: M0: Tanpa Mulsa, M1: Mulsa Jerami Padi, M2: Mulsa Alang-alang, M3: Mulsa Sekam Padi dan faktor kedua yaitu pemberian bokhasi kandang sapi yang ditempatkan sebagai anak petak dengan 4 taraf perlakuan yaitu: B0: Tanpa Bokhasi, B1: Bokhasi kandang sapi 10 ton/ha, B2: Bokhasi kandang sapi 20 ton/ha, B3: Bokhasi kandang sapi 30 ton/ha. Penelitian ini dilakukan dengan 3 ulangan. Parameter pengamatan yaitu: tinggi tanaman, jumlah daun, panjang buah, jumlah buah, lilit buah, berat buah persampel, dan berat buah perplot. Hasil penelitian menunjukkan bahwa: 1) Pemberian mulsa organik berpengaruh nyata pada pengamatan tinggi tanaman dengan perlakuan terbaik M1 (mulsa jerami padi). 2) Pemberian bokhasi kandang sapi berpengaruh nyata pada semua parameter. 3) Hasil analisa interaksi berpengaruh nyata pada pengamatan berat buah persampel dengan perlakuan terbaik M3B3 (Mulsa sekam padi + Bokhasi kandang sapi 30 ton/ha).

Kata Kunci: pare, bokhasi kandang sapi, mulsa organik.
\end{abstract}

\begin{abstract}
Bitter melon is fast-growing favorable vegetable these days. Nevertheless, there is limited study about it. The study aims to determine the Response of Giving Bokhasi Cow Cages and Various Organic Mulch Against Growth and Production of Bitter Melon. The study was conducted at the University of Medan Area Experimental Garden on Jl. PBSI No.1 Medan Estate with a height of 23 meters above sea level. The design used in the study was a factorial Split Plot Design (RPT) consisting of 2 factors. The first factor is the provision of organic mulch which is placed as the main plot of 4 treatments, namely: M0: without mulch, M1: rice straw mulch, M2: alang-alang Mulch, M3: rice husk mulch and the second factor is the provision of cattle cages placed as a subplot of 4 treatments, namely: B0: without bokhasi cowshed, B1: bokhasi cowshed 10 tons/ha, B2: bokhasi cowshed 20 tons/ha, B3: bokhasi cowshed 30 tons/ha. This research with 3 replications. Observation parameters of plant height, number of leaves, fruit length, number of fruits, fruit wrap, sample weight, and plot weight. The results showed that: 1) Organic mulch administration significantly affected plant height observations with the best treatment of M1 (rice straw mulch). 2) Giving bokhasi cowshed significantly affected all parameters. 3) The results of the interaction analysis have a significant effect on observing the weight of the sample with the best treatment of M3B3 (rice husk mulch + bokhasi cattle cage 30 tons /ha).

Key Words: bitter melon, bokhasi cow cages, organic mulch
\end{abstract}

How to Cite: Anna, N.R. Erwin, P. \& Gusmeizal. (2020). Respon Pemberian Bokhasi Kandang Sapi Dan Berbagai Mulsa Organik terhadap Pertumbuhan dan Produksi Tanaman Pare (Momordica Charantia L.). Jurnal Ilmiah Pertanian (JIPERTA), 2(1): 1-10

*E-mail: ritongga21@gmail.com ISSN 2550-1305 (Online)

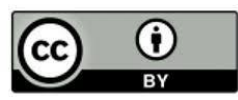


Anna Milasarah Ritongga, Erwin Pane \& Gusmeizal, Respon Pemberian Bokhasi Kandang Sapi Dan Berbagai Mulsa Organik terhadap Pertumbuhan dan Produksi Tanaman Pare (Momordica Charantia L.)

\section{PENDAHULUAN}

Pare (Paria) merupakan sayuran buah yang mulai diminati semenjak diketahuinya kandungan zat dan varietas-varietas baru yang lebih unggul dalam hal rasa dan penampilan tanaman. Akhirnya sayuran ini mampu merambah supermarket. Langkah maju ini menunjukkan bahwa paria telah membentuk citra tersendiri (Bastari dkk, 2017). Tanaman pare (Momordica charantia L.) merupakan tanaman semusim yang bersifat merambat. Rasa pahit pada tanaman pare terutama pada daun dan buah disebabkan oleh kandungan zat glukosida yang disebut momordisin. Zat yang menimbulkan rasa pahit mempunyai manfaat bagi kesehatan, diantaranya untuk menyembuhkan kencing manis, wasir, kemandulan, menambah produksi asi, dan merangsang nafsu makan (Hidayat dkk, 2015).

Pare termasuk salah satu tanaman sayur yang berpotensi komersil bila dibudidayakan secara intensif dalam sekala agribisnis. Hasil laporan tahunan Dinas Pertanian Sumatera Utara (2015) produksi pare masih tergolong sangat rendah dengan luas lahan yang kurang dari 1 ha dan produksi kurang dari 1 ton/ha, dengan total produksi per tahun 10,5 ton dengan luas areal 13,4 ha. Sehingga dalam laporan tahunan Dinas Pertanian Tanaman Pangan tentang produksi tanaman pare dianggap tidak ada karena produksinya sangat rendah.

Petani sudah mulai melakukan budidaya yang mengarah pada pertanian organik mulai dari pemupukan sampai pada pengendalian Organisme Pengganggu Tanaman (OPT). Jika dilihat berdasarkan sumber bahan yang digunakan, pupuk dibedakan menjadi pupuk anorganik dan pupuk organik, berdasarkan bentuk pupuk organik dibagi menjadi pupuk organik cair (POC) dan pupuk padat, pupuk padat umumnya mempunyai kelarutan yang beragam mulai yang mudah larut air sampai yang sukar larut (Simajuntak dkk., 2019). Salah satu jenis pupuk organik padat adalah pupuk Bokhasi. Bokhasi merupakan hasil fermentasi bahan organik dari limbah pertanian (pupuk kandang, jerami, sekam serbuk gergaji) dengan bantuan bakteri pengurai bahan organik (Gao et al, 2012 dalam Tabun 2017). Berdasarkan sumber bahan organiknya, terdapat beberapa jenis bokhasi yang dapat digunakan oleh petani antara lain bokhasi jerami, bokhasi pupuk kandang, bokhasi legume, dan lain-lain. Hasil penelitian Ichsan (2017) menyatakan bahwa pupuk bokashi kandang sapi memiliki pengaruh terhadap pertumbuhan dan hasil budidaya tanaman pare (Berutu dkk., 2019 ; Nubriama dkk., 2019). Dalam budidaya pare kita harus menjaga kelembapan tanah. Pada umumnya petani pare dalam budidaya menggunakan mulsa plastik hitam perak untuk menjaga kelembapan tanah serta menekan pertumbuhan gulma (Wahyudi dkk., 2019). Namun mulsa plastik ini memiliki harga yang cukup mahal dikalangan petani.

Mulsa dapat berupa bahan organik. Mulsa organik meliputi semua bahan sisa pertanian yang secara ekonomis kurang bermanfaat seperti jerami padi, batang jagung, batang kacang tanah, pelepah daun pisang, daun tebu, alang-alang dan serbuk gergaji, dengan adanya bahan mulsa diatas permukaan tanah, air hujan akan ditahan oleh bahan mulsa tersebut sehingga agregat tanah tetap stabil dan terhindar dari proses penghancuran dan erosi. Ketersedian bahan-bahan organik seperti alang-alang. Jerami padi dan sekam padi yang umumnya tidak dimanfaatkan dapat menggantikan 
penggunaan mulsa plastik perak. Berdasarkan data BPS (2018) produksi padi di Indonesia sebesar 56,54 juta ton Gabah Kering Giling (GKG), sedangkan produksi jerami padi yang dihasilkan dapat mencapai $50 \%$ dari produksi gabah kering panen.

Berdasarkan uraian di atas maka dilakukanpenelitian dengan judul "Respon Pemberian Bokhasi Kandang Sapi dan Berbagai Mulsa Organik Terhadap Pertumbuhan dan Produksi Tanaman Pare (Momordica charantia L.)".

\section{METODE PENELITIAN}

\section{Rancangan Percobaan}

Penelitian ini dilakukan dengan menggunakan Rancangan Petak Terbagi (RPT) Faktorial yang terdiri dari 2 Faktor Perlakuan yaitu:

1. Mulsa organik dengan notasi (M) sebagai petak utama terdiri dari 4 taraf perlakuan yaitu:

$$
\begin{aligned}
& \text { M0 }=\text { Kontrol (Tanpa Penggunaan Mulsa) } \\
& \text { M1 }=\text { Mulsa Jerami }(3,6 \mathrm{~kg} / \mathrm{m} 2) \\
& \text { M2 }=\text { Mulsa Alang-alang }(3,6 \mathrm{~kg} / \mathrm{m} 2) \\
& \text { M3 }=\text { Mulsa Sekam Padi }(3,6 \mathrm{~kg} / \mathrm{m} 2)
\end{aligned}
$$

2. Pemberian pupuk bokhasi kandang sapi dengan notasi (B) sebagai anak petak yang terdiri 4 taraf perlakuan yaitu:

B0 = Kontrol (Tanpa Bokhasi)

B1 = Bokhasi kandang sapi 10 ton $/$ ha $(1,2 \mathrm{~kg} / \mathrm{m} 2)$

B2 = Bokhasi kandang sapi 20 ton $/$ ha $(2,4 \mathrm{~kg} / \mathrm{m} 2)$

B3 = Bokhasi kandang sapi 30 ton $/$ ha $(3,6 \mathrm{~kg} / \mathrm{m} 2)$

total jumlah tanaman keseluruhan 288 tanaman. Dalam satu plot penelitian terdiri 2 sampel dan total jumlah sampel dalam penelitian ini sebanyak 96 tanaman.

\section{Pembuatan Pupuk Bokhasi Kandang Sapi}

Langkah awal yang dilakukan adalah mengumpulkan kototan sapi sebanyak $100 \mathrm{~kg}$. Dengan komposisi bokhasi kandang sapi yaitu sekam padi sebanyak 10\%, dedak sebanyak 5\%, abu sekam 10\%. Air 10 liter dan EM4 $200 \mathrm{ml}$ untuk mendekomposisi bahan organik dan gula merah sebanyak 200 gram sebagai bahan makanan mikroorganisme. Pembuatan bokhasi ini mengacu pada (Badan Penelitian Dan Pengembangan Pertanian, 2007).

\section{Persiapan Mulsa Organik dan Lahan}

Mulsa organik yang disediakan yaitu: jerami padi, alang-alang, sekam padi. Pemberian mulsa organik yaitu jerami padi, alang-alang, dan sekam padi disebar secara merata pada masing-masing plot yang telah disediakan sesuai dengan perlakuan yang telah ditentukan, mulsa organik disebar diatas permukaan plot dengan dosis $3.6 \mathrm{~kg}$ untuk satu plot. Pemberian mulsa organik dilakukan satu munggu setelah pindah tanam.

Setelah penyiapan mulsa maka lahan dibersihkan dari gulma, sampah, dan kayu yang terdapat di sekitar areal. Setelah areal dibersihkan, tanah di cangkul sampai gembur. Kemudian dibentuklah plot-plot dengan ukuran $100 \mathrm{~cm}$ x $120 \mathrm{~cm}$, dengan ketinggian $30 \mathrm{~cm}$. Jarak antar plot $50 \mathrm{~cm}$ dan jarak antar ulangan $100 \mathrm{~cm}$. Penyemaian dilakukan dengan membuat plot persemaian dengan ukuran $150 \mathrm{~cm}$ x $200 \mathrm{~cm}$. Kemudian 
Anna Milasarah Ritongga, Erwin Pane \& Gusmeizal, Respon Pemberian Bokhasi Kandang Sapi Dan Berbagai Mulsa Organik terhadap Pertumbuhan dan Produksi Tanaman Pare (Momordica Charantia L.)

dibuat naungan untuk menghindari bibit terkena sinar matahari langsung. Pemindahan bibit pare ke lahan dapat dilakukan ketika bibit berumur 15 hari. dengan waktu penanaman yang paling baik adalah pagi hari dan sore hari ketika suhu udara dan terik matahari tidak terlalu tinggi.

Aplikasi Pupuk Bokhasi Kandang Sapi

Aplikasi pupuk bokhasi kandang sapi dilakukan pada 1 minggu sebelum tanam. Pupuk bokhasi kandang sapi dilakukan dengan membagi dosis yang sudah ditentukan untuk masing-masing perlakuan, kemudian pupuk bokhasi kandang sapi di aplikasikan pada masing-masing plot sesuai perlakuan yang telah ditentukan.

\section{Pemeliharaan Tanaman}

Pemeliharaan tanaman meliputi penyiraman yang dilakukan dua kali sehari pada pagi dan sore hari. Pemasangan ajir dan para-para dilakukan pada saat 1 minggu setelah pindah tanam karena dianggap sudah memiliki tunas. Penyiangan dilakukan mulai dari bibit dipindahkan ke lapangan dengan interval waktu 1 minggu sekali. Pemangkasan dilakukan setelah tanaman berumur 3 minggu, pemangkasan dilakukan dengan memangkas tunas yang lebih tinggi dari pada batang utama karena dianggap tidak produktif. Pemangkasan selanjutnya dilakukan setelah tanaman berumur 6 minggu. Penyulaman dilakukan apabila ada tanaman yang mati maka akan langsung dilakukan penggantian dengan tanaman baru yang lebih baik. Penyulaman dilakukan maksimal 5 hari setelah tanam. Pembungkusan buah untuk meminimalisir serangan hama dan penyakit. Pembungkusan bertujuan untuk mejaga buah terlihat segar dan kondisi kulit lebih mulus. Pembungkusan buah dilakukan dengan menggunakan kantong plastik. Pengendalian Hama Dan Penyakit Pengendalian hama dan penyakit dilakukan dengan cara menjaga kebersihan lahan dari gulma yang dapat menjadi inang bagi hama dengan cara pengutipan yaitu mengambil atau membasmi hama dengan tangan sendiri. Apabila hama terdapat 21-26 hama per tanaman maka perlu dilakukan penyemprotan insektisida Curacron 100 ml/15 liter air.

\section{Analisis Data}

Dalam studi ini parameter yang diukur meliputi panjang tanaman, jumlah helaian daun, panjang buah, jumlah buah, lilit buah, berat buah per sampel, dan berat buah per plot. Data tersebut kemudian diolah dengan analisis statistika. 


\section{HASIL DAN PEMBAHASAN}

\section{Parameter pertumbuhan fisiologis}

Hasil analisis statistic terhadap tinggi tanaman setelah perlakukan disajikan pada Tabel 1.

Table 1. Rangkuman Analisis Ragam Tinggi Tanaman Pare Akibat Pemberian Bokhasi Kandang Sapi dan Berbagai Mulsa Organik Pada Umur 1 Sampai 6 MSPT

\begin{tabular}{ccccccccc}
\hline \multirow{2}{*}{ SK } & \multicolumn{9}{c}{ F.hitung Pada Umur } & \multicolumn{2}{c}{ F Tabel } \\
\cline { 2 - 9 } & $1 \mathrm{MSPT}$ & $2 \mathrm{MSPT}$ & $3 \mathrm{MSPT}$ & $4 \mathrm{MSPT}$ & $5 \mathrm{MSPT}$ & $6 \mathrm{MSPT}$ & $\mathrm{F} .05$ & F.01 \\
\hline Kelompok & $6.70 *$ & $2.95 \mathrm{tn}$ & $2.99 \mathrm{tn}$ & $4.97 \mathrm{tn}$ & $1.36 \mathrm{tn}$ & $3.28 \mathrm{tn}$ & 5.14 & 10.92 \\
PU & $0.87 \mathrm{tn}$ & $0.39 \mathrm{tn}$ & $0.97 \mathrm{tn}$ & $5.12 *$ & $2.03 *$ & $4.85 *$ & 4.76 & 9.78 \\
AP & $4.69 *$ & $2.39 *$ & $0.76 \mathrm{tn}$ & $4.36 *$ & $1.72 \mathrm{tn}$ & $3.20 *$ & 3.01 & 4.72 \\
PUxAP & $1.08 \mathrm{tn}$ & $3.29 * *$ & $1.89 \mathrm{tn}$ & $2.95 *$ & $1.19 \mathrm{tn}$ & $0.76 \mathrm{tn}$ & 2.30 & 3.25 \\
\hline KK (a) & $6.48 \%$ & $8.56 \%$ & $6.25 \%$ & $4.17 \%$ & $9.15 \%$ & $3.07 \%$ & & \\
KK (b) & $7.75 \%$ & $6.50 \%$ & $6.78 \%$ & $4.80 \%$ & $7.51 \%$ & $3.76 \%$ & & \\
\hline
\end{tabular}

Kombinasi perlakuan petak utama (mulsa organik) dan anak petak (bokhasi kandang sapi) berpengaruh tidak nyata pada pengamatan umur 1, 35 dan 6 MSPT, namum berpengaruh nyata pada pengamatan umur 4 MSPT, dan berpengaruh sangat nyata pada pengukuran umur 2 MSPT terhadap panjang tanaman pare. Hasil penelitian ini diduga bahwa pemberian pupuk yang seimbang bagi tanaman dapat mendukung pertumbuhan tanaman dimana dosis dari B3 (30 ton/ha) lebih besar dari B2 dan B1 (10 ton/ha) lebih kecil dari B2. Hasil penelitian ini sejalan dengan pendapat Andriwan Irawati (2017) yang menyatakan bahwa keseimbangan unsur hara dalam tanah perlu dijaga karena dapat mengakibatkan terganggunya tanaman. Hasil penelitian diduga bahwa kombinasi mulsa sekam padi dan bokhasi kandang sapi memberikan nutrisi yang seimbang bagi tanaman sehingga dapat menunjang pertumbuhan tinggi tanaman pare.

penggunaan mulsa organik berpengaruh nyata pada umur 4 sampai 6 MSPT, pada tabel 4, menunjukkan bahwa perlakuan M1 (mulsa jerami padi) merupakan perlakuan terbaik pada umur 6 MSPT, tidak berbeda nyata dengan perlakuan M2 (Mulsa Alangalang) dan M3 (Mulsa Sekam), serta berbeda nyata dengan perlakuan M0 (tanpa mulsa).

Hasil penelitian ini diduga mulsa jerami padi pada umur 4 sampai 6 MSPT Sudah mulai terdekomposisi pada bagian bawah mulsa sehingga mampu mendukung kebutuhan hara tanaman. Hal ini didukung oleh hasil penelitian Harsono (2012), yang menyatakan bahwa pemberian mulsa jerami memberikan kandungan $\mathrm{N}$ total sebesar $0.30 \%$ dan $\mathrm{K}$ tersedia $0.70 \%$, sehingga dengan unsur hara yang diberikan mendorong pertumbuhan tanaman pare. Sedangkan mulsa alang-alang dan sekam padi lambat terurai dan mudah kering akibat sinar matahari sehingga hanya menekan pertumbuhan gulma dan melindungi tanah dari percikan air hujan.

Pemberian Bokhasi kandang sapi (anak petak) berpengaruh nyata pada umur 1, 2, 4 dan 6 MSPT. Tabel 4. Menunjukkan bahwa perlakuan B2 (20 ton/ha) menghasilkan pertumbuhan terbaik (1434.73) pada umur 6 MSPT, tidak berbeda nyata dengan 
Anna Milasarah Ritongga, Erwin Pane \& Gusmeizal, Respon Pemberian Bokhasi Kandang Sapi Dan Berbagai Mulsa Organik terhadap Pertumbuhan dan Produksi Tanaman Pare (Momordica Charantia L.)

perlakuan B0 (tanpa bokhasi) dan B3 (30 ton/ha) serta berbeda nyata dengan perlakuan B1 (10 ton/ha). Hasil penelitian ini diduga bahwa pemberian pupuk yang seimbang bagi tanaman dapat mendukung pertumbuhan tanaman dimana dosis dari B3 (30 ton/ha) lebih besar dari B2 dan B1 (10 ton/ha) lebih kecil dari B2. Hasil penelitian ini sejalan dengan pendapat Zainuddin (2015) yang menyatakan bahwa keseimbangan unsur hara dalam tanah perlu dijaga karena dapat mengakibatkan terganggunya tanaman.

Hasil penelitian diduga bahwa kombinasi mulsa sekam padi dan bokhasi kandang sapi memberikan nutrisi yang seimbang bagi tanaman sehingga dapat menunjang pertumbuhan tinggi tanaman pare.

Jumlah Daun

Pengaruh kombinasi perlakuan pada jumlah daun dapat dilihat pada Tabel 2.

Table 2. Rangkuman Analisis Ragam Jumlah Daun Tanaman Pare Akibat Pemberian Berbagai Mulsa Organik dan Bokhasi

Kandang Sapi Pada Umur 1 Sampai 6 MSPT

\begin{tabular}{|c|c|c|c|c|c|c|c|c|}
\hline \multirow{2}{*}{ SK } & \multicolumn{6}{|c|}{ F.hitung Pada Umur } & \multicolumn{2}{|c|}{ F Tabel } \\
\hline & $1 \mathrm{MSPT}$ & $2 \mathrm{MSPT}$ & 3 MSPT & 4 MSPT & $5 \mathrm{MSPT}$ & $6 \mathrm{MSPT}$ & F.05 & F.01 \\
\hline Kelompok & $6.91 *$ & $8.11 *$ & $1.32 \mathrm{tn}$ & $3.50 \mathrm{tn}$ & $0.20 \mathrm{tn}$ & $2.59 \mathrm{tn}$ & 5.14 & 10.92 \\
\hline PU & $0.94 \mathrm{tn}$ & $3.92 \mathrm{tn}$ & $0.72 \mathrm{tn}$ & $1.28 \mathrm{tn}$ & $0.04 \mathrm{tn}$ & $1.18 \mathrm{tn}$ & 4.76 & 9.78 \\
\hline AP & $3.06 *$ & $3.26 *$ & $1.77 \mathrm{tn}$ & $0.76 \mathrm{tn}$ & $6.84 * *$ & $1.06 \mathrm{tn}$ & 3.01 & 4.72 \\
\hline PUxAP & $1.05 \mathrm{tn}$ & $0.58 \mathrm{tn}$ & $0.76 \mathrm{tn}$ & $1.84 \mathrm{tn}$ & $0.82 \operatorname{tn}$ & $2.40 *$ & 2.30 & 3.25 \\
\hline KK (a) & $8.52 \%$ & $4.56 \%$ & $10.06 \%$ & $8.00 \%$ & $8.88 \%$ & $5.66 \%$ & & \\
\hline KK (b) & $9.68 \%$ & $12.80 \%$ & $9.20 \%$ & $10.77 \%$ & $7.89 \%$ & $6.93 \%$ & & \\
\hline
\end{tabular}

Berdasarkan hasil analisis ragamnya sebagaimana yang disajikan pada tabel 2, menunjukkan bahwa perlakuan petak utama (mulsa organik) tidak berpengaruh nyata terhadap jumlah daun tanaman pare dari umur 1 sampai 6 MSPT. Pengaruh anak petak berpengaruh nyata pada umur 2 MSPT, berpengaruh sangat nyata pada umur 5 MSPT, dan tidak berpengaruh nyata pada umur 3, 4 dan 6 MSPT. Interaksi petak utama dan anak petak berpengaruh nyata pada umur 6 MSPT dan berpengaruh tidak nyata 1 sampai 5 MSPT.

Hasil penelitian diduga bahwa mulsa organik mulai terdekomposisi tetapi unsur hara tidak tersedia bagi tanaman untuk meningkatkan jumlah daun, melainkan hanya menekan pertumbuh Hasil penelitian diduga pemberian bokhasi kandang sapi yang memiliki dosis yang semakin banyak dapat menunjang pertumbuhan jumlah daun tanaman pare dikarenakan bokhasi kandang sapi memngandung beberapa unsur hara yang dibutuhkan tanaman seperti unsur hara makro N, P, K. Hal ini sejalan dengan penelitian alif (2017) yang menyatakan bahwa pemberian dosis pupuk bokhasi kandang sapi dengan dosis 30 ton/ha dapat mempertahankan pertumbuhan tanaman.an gulma dan memperlambat proses transpirasi.

Interaksi petak utama dan anak petak berpengaruh nyata pada umur 6 MSPT, dimana perlakuan terbaik terdapat pada perlakuan M3B3 $(197,00)$ berbeda nyata dengan perlakuan M0B3, M1B0, M2B1, M2B2, dan M3B0. Hasil penelitian diduga bahwa dengan mulsa sekam padi, hara dari pupuk bokhasi tidak hilang dan dapat diserap oleh tanaman. 


\section{Analisis Parameter Produksi}

perlakuan petak utama (mulsa) tidak berpengaruh nyata terhadap panjang buah tanaman pare dari umur 1 sampai 6 MSPT. Perlakuan anak petak (bokhasi kandang sapi) tidak berpengaruh nyata pada umur 2 dan 5 MSPT, berpengaruh nyata pada pengukuran umur 3, 4 dan 6 MSPT dan berpengaruh sangat nyata terhadap panjang buah tanaman pare pada umur 1 MSPT. Rangkuman Analisis Ragam Panjang Buah Tanaman Pare Akibat Pemberian Berbagai Mulsa Organik dan Bokhasi Kandang Sapi Pada Umur panen 1 Sampai ke-6 disajikan pada Tabel 3.

Table 3. Rangkuman Analisis Ragam Panjang Buah Tanaman Pare Akibat Pemberian Berbagai Mulsa Organik dan Bokhasi Kandang Sapi Pada Umur panen 1 Sampai ke-6

\begin{tabular}{ccccccccc}
\hline \multirow{2}{*}{ SK } & \multicolumn{9}{c}{ F.hitung Pada Umur } & \multicolumn{2}{c}{ F Tabel } \\
\cline { 2 - 10 } & Panen 1 & Panen 2 & Panen 3 & Panen 4 & Panen 5 & Panen 6 & F.05 & F.01 \\
\hline Kelompok & $1.92 *$ & 0.89 tn & 0.89 tn & 1.10 tn & 2.62 tn & $5.57 *$ & 5.14 & 10.92 \\
PU & 1.34 tn & $2.96 \mathrm{tn}$ & $2.73 \mathrm{tn}$ & $1.18 \mathrm{tn}$ & $0.38 \mathrm{tn}$ & $3.57 \mathrm{tn}$ & 4.76 & 9.78 \\
AP & $5.95 * *$ & $0.30 \mathrm{tn}$ & $3.46 *$ & $4.53 *$ & $0.50 \mathrm{tn}$ & $4.20 *$ & 3.01 & 4.72 \\
PUxAP & $1.67 \mathrm{tn}$ & $1.72 \mathrm{tn}$ & $1.62 \mathrm{tn}$ & $1.31 \mathrm{tn}$ & $0.85 \mathrm{tn}$ & $1.35 \mathrm{tn}$ & 2.30 & 3.25 \\
\hline KK (a) & $9.40 \%$ & $6.94 \%$ & $3.25 \%$ & $6.14 \%$ & $6.15 \%$ & $7.00 \%$ & & \\
KK (b) & $6.28 \%$ & $5.34 \%$ & $5.79 \%$ & $8.13 \%$ & $7.31 \%$ & $6.43 \%$ & & \\
\hline
\end{tabular}

Hasil penelitian ini sejalan dengan pendapat Tola et al. (2007) yang menyatakan pengaruh bokhasi kandang sapi tergantung pada dosis kotoran sapi yang digunakan dalam penelitian. Secara biologis pupuk bokhasi dapat meningkatkan aktivitas mikroorganisme tanah. Zahrah (2012) juga menyatakan bahwa pupuk bokhasi mengandung mikroorganisme bermanfaat yang merupakan bagian integral dari tanah mampu menyediakan hara tanaman melalui proses daur ulang serta membentuk struktur tanah yang sesuai dengan pertumbuhan tanaman

Hasil analisis statistika terhadap jumlah buah disajikan pada tabel 3.

Table 4. Rangkuman Analisis Ragam Jumlah Buah Persampel Tanaman Pare Akibat Pemberian Bokhasi Kandang Sapi Dan Berbagai Mulsa Organik Pada Umur panen 1 Sampai panen ke-6

\begin{tabular}{|c|c|c|c|c|c|c|c|c|}
\hline \multirow{2}{*}{ SK } & \multicolumn{6}{|c|}{ F.hitung Pada Panen } & \multicolumn{2}{|c|}{ F Tabel } \\
\hline & Panen 1 & Panen 2 & Panen 3 & Panen 4 & Panen 5 & Panen 6 & F.05 & F.01 \\
\hline Kelompok & 1.44 tn & $1.44 \mathrm{tn}$ & $1.56 \mathrm{tn}$ & $0.60 \mathrm{tn}$ & $3.17 \mathrm{tn}$ & 0.04 tn & 5.14 & 10.92 \\
\hline PU & $1.00 \mathrm{tn}$ & $0.89 \mathrm{tn}$ & $1.24 \mathrm{tn}$ & $0.41 \mathrm{tn}$ & $2.37 \mathrm{tn}$ & $0.30 \mathrm{tn}$ & 4.76 & 9.78 \\
\hline $\mathrm{AP}$ & $1.63 \mathrm{tn}$ & $0.14 \mathrm{tn}$ & $3.36 *$ & 2.64 tn & $0.87 \mathrm{tn}$ & $3.12 *$ & 3.01 & 4.72 \\
\hline PUxAP & $1.57 \mathrm{tn}$ & $2.27 \mathrm{tn}$ & $0.63 \mathrm{tn}$ & $0.84 \mathrm{tn}$ & $0.90 \mathrm{tn}$ & $0.43 \mathrm{tn}$ & 2.30 & 3.25 \\
\hline $\mathrm{KK}$ (a) & $17.47 \%$ & $15.00 \%$ & $12.82 \%$ & $15.90 \%$ & $18.06 \%$ & $18.14 \%$ & & \\
\hline KK (b) & $12.80 \%$ & $19.66 \%$ & $11.15 \%$ & $18.42 \%$ & $18.32 \%$ & $16.58 \%$ & & \\
\hline
\end{tabular}

Berdasarkan data pada tabel 4, menunjukkan bahwa petak utama (mulsa organik) tidak berpengaruh nyata dari panen 1 sampai panen 6 . Hasil penelitian diduga bahwa 
Anna Milasarah Ritongga, Erwin Pane \& Gusmeizal, Respon Pemberian Bokhasi Kandang Sapi Dan Berbagai Mulsa Organik terhadap Pertumbuhan dan Produksi Tanaman Pare (Momordica Charantia L.)

mulsa organik yang digunakan tidak menyumbangkan unsur hara kepada tanaman melainkan hanya menekan pertumbuhan gulma dan transpirasi, sehingga tidak menunjukkan hasil yang nyata terhadap jumlah buah tanaman pare. Hasil penelitian Harsono Puji (2012) menyatakan mulsa serasah padi dapat menyumbangkan C organik, $\mathrm{P}$ tersedia, $\mathrm{N}$ total dan $\mathrm{K}$ tersedia apabila mulsa sudah terdekomposisi.

Perlakuan anak petak (bokhasi kandang sapi), dari tabel 8 dapat dilihat bahwa bokhasi berpengaruh nyata pada panen ke-6, dengan perlakuan terbaik B2 (20 ton/ha) tidak berbeda nyata dengan perlakuan lainnya. Hasil penelitian menunjukkan bahwa pemberian bokhasi yang cukup dan optimal memberikan hasil yang baik, seperti pada pengukuran panjang buah yang menunjukkan bahwa dosis pupuk B2 (20 ton/ha) adalah dosis yang terbaik. Menurut annas dkk (2017) pengaruh bokhasi kotoran sapi tergantung pada dosis yang digunakan dalam penelitian.

Interaksi petak utama dan anak petak pada tabel 8, menunjukkan tidak berpengaruh nyata pada panen 1 sampai panen ke 6 terhadap jumlah buah persampel, hasil penelitian diduga bahwa mulsa dan bokhasi tidak menyumbang kan hara yang cukup sampai pada masa panen, sama seperti pengaruh interaksi terhadap panjang buah yang tidak berpengaruh nyata.

Berdasarkan hasil analisis ragamnya yang disajikan pada tabel 4, menunjukkan bahwa petak utama (mulsa organik) berpengaruh tidak nyata terhadap jumlah buah sampel dari panen 1 sampai panen 6. Anak petak (bokhasi kandang sapi) nyata berpengaruh pada panen 3 dan 6, sedangkan pada panen lainya tidak nyata berpengaruh terhadap jumlah buah sampel. Interaksi petak utama dan anak petak tidak berpengaruh nyata pada panen 1 sampai panen 6 terhdap jumlah buah persampel. Hasil penelitian diduga bahwa mulsa organik yang digunakan tidak menyumbangkan unsur hara kepada tanaman melainkan hanya menekan pertumbuhan gulma dan transpirasi, sehingga tidak menunjukkan hasil yang nyata terhadap jumlah buah tanaman pare. Hasil penelitian Hartatik (2006) menyatakan mulsa serasah padi dapat menyumbangkan $\mathrm{C}$ organik, $\mathrm{P}$ tersedia, $\mathrm{N}$ total dan $\mathrm{K}$ tersedia apabila mulsa sudah terdekomposisi.

Selain itu, Berdasarkan hasil analisis ragamnya sebagaimana yang disajikan pada tabel 11, menunjukkan bahwa petak utama (mulsa organik) berpengaruh tidak nyata terhadap lilit buah tanaman pare dari umur panen 1 sampai dengan panen 6 . Anak petak (bokhasi kandang sapi) berpengaruh tidak nyata pada umur panen 4 sampai panen ke-6, berpengaruh nyata pada panen 2 dan 3 serta berpengaruh sangat nyata pada panen 1 terhadap lilit buah tanaman pare. panen pertama unsur hara yang diberikan oleh bokhasi kandang sapi masih tersedia seperti N, P, K dan cukup untuk pembentukan buah pertama sehingga menghasilkan buah yang cukup bagus. Hal ii sejalan dengan pendapat Hidayat, (2014) yang menyatakan bahwa unsur P memiliki manfaat yaitu memacu pembentukan bunga dan pematangan buah/biji, sehingga mempercepat masa panen. 
Tabel 4. Rangkuman Analisis Ragam Berat Buah Sampel Tanaman Pare Akibat Pemberian Bokhasi Kandang Sapi Dan Berbagai Mulsa Organik Pada Umur panen 1 Sampai panen ke-6

\begin{tabular}{ccccccccc}
\hline \multirow{2}{*}{ SK } & \multicolumn{3}{c}{ F.hitung Pada Umur } & \multicolumn{3}{c}{ F Tabel } \\
\cline { 2 - 9 } & Panen 1 & Panen 2 & Panen 3 & Panen 4 & Panen 5 & Panen 6 & F.05 & F.01 \\
\hline Kelompok & $1.77 \mathrm{tn}$ & $0.76 \mathrm{tn}$ & $0.98 \mathrm{tn}$ & $1.37 \mathrm{tn}$ & $7.17 *$ & $13.02 * *$ & 5.14 & 10.92 \\
PU & $1.66 \mathrm{tn}$ & $4.14 \mathrm{tn}$ & $3.34 \mathrm{tn}$ & $0.26 \mathrm{tn}$ & $1.65 \mathrm{tn}$ & $2.52 \mathrm{tn}$ & 4.76 & 9.78 \\
AP & $3.14 *$ & $1.83 \mathrm{tn}$ & $0.47 \mathrm{tn}$ & $4.00 *$ & $0.49 \mathrm{tn}$ & $3.33 *$ & 3.01 & 4.72 \\
PUxAP & $1.06 \mathrm{tn}$ & $2.92 *$ & $0.55 \mathrm{tn}$ & $0.61 \mathrm{tn}$ & $0.51 \mathrm{tn}$ & $1.17 \mathrm{tn}$ & 2.30 & 3.25 \\
\hline KK (a) & $16.02 \%$ & $17.62 \%$ & $10.45 \%$ & $17.85 \%$ & $15.55 \%$ & $10.52 \%$ & & \\
KK (b) & $20.68 \%$ & $14.68 \%$ & $26.46 \%$ & $21.13 \%$ & $16.25 \%$ & $15.91 \%$ & &
\end{tabular}

Data penelitian menunjukkan bahwa perlakuan bokhasi yang semakin banyak diberikan akan menunjukkan hasil yang semakin baik jika dilihat dari tabel 11, perlakuan B1, B2 dan B3 hasilnya semakin naik. Dengan demikian diduga bahwa perlakuan bokhasi yang semakin tinggi akan menunjukkan hasil yang semakin baik. Hal ini sejalan dengan penelitian Wantania Indhira Tacoh dan Kaunangan, (2016), yang menyimpulkan bahwa semakin tinggi level pemupukan kandang sapi maka semakin tinggi berat malai, dikarenakan adanya pemberian pupuk bokhasi kandang sapi yang memperbaiki sifat fisik, kimia dan biologi tanah.

\section{SIMPULAN}

Pemberian mulsa organik dapat meningkatkan pertumbuhan tinggi tanaman pada umur 4 sampai 6 MSPT dengan perlakuan terbaik M1 nyata berbeda dengan perlakuan lainnya kecuali M3. Pemberian bokhasi kandang sapi dapat meningkatkan pertumbuhan tanaman, tinggi tanaman berpengaruh nyata pada umur 1, 2, 4, dan 6 MSPT dengan perlakuan terbaik B2 dan jumlah daun berpengaruh sangat nyata pada umur 5 MSPT dengan perlakuan terbaik B3. Sedangkan panjang buah,jumlah buah, lilit buah, dan berat buah perplot berpengaruh nyata pada panen ke-3 kecuali berat buah persampel.

\section{DAFTAR PUSTAKA}

Alif S. (2017). Kiat Sukses Budidaya Cabai Rawit: Bio Genesis.

Annas Setya AF, Nugroho A, \& Soelistyono R. (2018). Kajian Penggunaan Beberapa Macam Pupuk Kandang Terhadap Pertumbuhan Dan Hasil Tanaman Bunga Kol (Brassica Oleraceea L.) Pada Jarak Tanam Yang Berbeda. Jurnal Produksi Tanaman, 5(6).

Bastari IL, Sipayung R, \& Ginting J. (2017). Respons Pertumbuhan dan Produksi Paria terhadap beberapa komposisi media tanam dan pemberian pupuk organik cair. Jurnal Online Agroekoteknologi, 5(4), 740-748.

Berutu, R., Aziz, R., \& Hutapea, S. (2019). Pengaruh Pemberian Berbagai Sumber Biochar dan Berbagai Pupuk Kandang terhadap Pertumbuhan dan Produksi jagung hitam (Zea mays L.). Jurnal Ilmiah Pertanian ( JIPERTA), 1(1), 16-25.

Harsono P. (2012). Mulsa organik: pengaruhnya terhadap lingkungan mikro, sifat kimia tanah dan keragaan cabai merah di tanah vertisol Sukoharjo pada musim kemarau. Jurnal Hortikultura Indonesia, 3(1), 35-41.

Hartatik W, \& Widowati L. (2006). Pupuk kandang. In (pp. 59-82): Pupuk organik dan pupuk hayati. Balai Besar Litbang Sumberdaya Lahan ....

Hidayat A. (2014). Optimalisasi Produksi Padi (Oryza Sativa L.) Menggunakan Sistem Sri Dengan Pengaturan Jarak Tanam Dan Pemberian Pupuk Fosfor Di Tanah Podsolik Merah Kuning. Universitas Islam Negeri Sultan Sarif Kasim Riau,

Hidayat IRS, Si M, Napitupulu RM, \& SP M. (2015). Kitab Tumbuhan Obat: Agriflo. 
Anna Milasarah Ritongga, Erwin Pane \& Gusmeizal, Respon Pemberian Bokhasi Kandang Sapi Dan Berbagai Mulsa Organik terhadap Pertumbuhan dan Produksi Tanaman Pare (Momordica Charantia L.)

Ichsan MC, Santoso I, \& Oktarina O. (2017). Uji Efektivitas Waktu Aplikasi Bahan Organik dan Dosis Pupuk Sp-36 dalam Meningkatkan Produksi Okra (Abelmoschus Esculentus). Agritrop: Jurnal Ilmu-Ilmu Pertanian (Journal of Agricultural Science), 14(2).

Irawati A, \& Kusnanto T. (2017). Pengaruh Aplikasi Pupuk Hayati Terhadap Sifat Kimia Tanah Pada Lahan Sawah. In: Balai Besar Pengkajian dan Pengembangan Teknologi Pertanian.

Nubriama, R., Pane, E., \& Hutapea, S. (2019). pengaruh pemberian pupuk organik cair kandang kelinci dan kompos limbah baglog pada pertumbuhan bibit Kakao (theobroma cacao l.) Di polibeg. Jurnal Ilmiah Pertanian (JIPERTA), 1(2), 143-152.

Simajuntak, M., Hasibuan, S., \& Maimunah, M. (2019). Efektivitas Penggunaan Bokashi Blotong Tebu dan Pemberian Pupuk Organik Cair Kulit Nanas Terhadap Produktifitas Tanaman Kecipir (Psophocarpus tetragonolobus L.). Jurnal Ilmiah Pertanian (JIPERTA), 1(2), 133-142.

Situmorang K. (2017). Pengaruh sistem olah tanah dan pemberian mulsa bagas jangka panjang pada lahan tebu pt. Gmp ratoon ke-1 periode 2 terhadap populasi dan biomassa cacing tanah serta populasi dan keanekaragaman mesofauna tanah.

Tabun AC, Ndoen B, Leo-Penu CL, Jermias JA, Foenay TA, \& Ndolu DA. (2017). Pemanfaatan limbah dalam produksi pupuk bokhasi dan pupuk cair organik di desa tuatuka kecamatan kupang timur. Jurnal Pengabdian Masyarakat Peternakan, 2(2).

Tacoh E, Rumambi A, \& Kaunang W. (2016). Pengaruh pemanfaatan pupuk bokasi feses sapi terhadap produksi sorgum varietas Kawali. ZOOTEC, 37(1), 88-95.

Wahyudi, A., Maimunah, M., \& Pane, E. (2019). Respon Pertumbuhan Dan Produksi Kacang Tanah (Arachis Hypogaea L.) Terhadap Pemberian Pupuk Kandang Kambing Dan Pupuk Organik Cair Bonggol Pisang. Jurnal Ilmiah Pertanian (JIPERTA), 1(1), 1-8.

Zahrah S. (2011). Aplikasi pupuk bokashi dan npk organik pada tanah ultisol untuk tanaman padi sawah dengan sistem SRI (System of Rice Intensification). Jurnal Ilmu Lingkungan, 5(02).

Zainuddin A. (2016). Pengaruh Pemberian Bokashi Kotoran Sapi Terhadap Pertumbuhan dan Produksi Rumput Gajah Mini (Pennisetum purpureum cv. Mott). 